\title{
Francesco MONTORSI, Production éditoriale et diffusion des récits arthuriens en France ( $\mathrm{XV}^{\mathrm{e}}-\mathrm{XVI}^{\mathrm{e}}$ siècles)
}

\author{
Maria Colombo Timelli
}

\section{OpenEdition \\ Journals}

\section{Édition électronique}

URL : https://journals.openedition.org/studifrancesi/44488

DOI : 10.4000/studifrancesi.44488

ISSN : 2427-5856

\section{Éditeur}

Rosenberg \& Sellier

\section{Édition imprimée}

Date de publication : 1 juin 2021

Pagination : 197

ISSN : 0039-2944

Référence électronique

Maria Colombo Timelli, «Francesco montorsı, Production éditoriale et diffusion des récits arthuriens en France ( $x v^{\mathrm{e}}-x v^{\mathrm{e}}$ siècles) », Studi Francesi [En ligne], 193 (LXV | I) | 2021, mis en ligne le 01 juillet 2021 , consulté le 15 octobre 2022. URL : http://journals.openedition.org/studifrancesi/44488 ; DOI : https:// doi.org/10.4000/studifrancesi.44488

Ce document a été généré automatiquement le 15 octobre 2022.

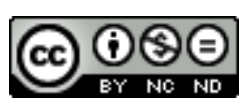

Creative Commons - Attribution - Pas d'Utilisation Commerciale - Pas de Modification 4.0 International - CC BY-NC-ND 4.0

https://creativecommons.org/licenses/by-nc-nd/4.0/ 


\title{
Francesco MONTORSI, Production éditoriale et diffusion des récits arthuriens en France ( $\mathrm{XV}^{\mathrm{e}}-\mathrm{XVI} \mathrm{I}^{\mathrm{e}}$ siècles)
}

\author{
Maria Colombo Timelli
}

\section{RÉFÉRENCE}

Francesco MONTORSI, Production éditoriale et diffusion des récits arthuriens en France ( $\mathrm{xV} \mathrm{V}_{-}$ XVI siècles), pp. 167-188.

1 Après avoir tiré un bilan sur la rareté des titres arthuriens imprimés en France par rapport à l'ensemble de la production éditoriale des premiers siècles - bilan bien connu des spécialistes du domaine, grâce aux recherches de Philippe Ménard, plus récemment de G. Matteo Roccati et de Sergio Cappello -, F.M. esquisse une comparaison avec les traditions des autres pays européens: Espagne, Italie, Angleterre, Allemagne; il en émerge que le succès de la matière arthurienne y est tout aussi limité. 